\title{
What Did God Promise Abraham
}

\author{
Michael A. Milton, $\mathrm{PhD}^{1}$ \\ ${ }^{1}$ Affiliation not available
}

September 8, 2021

So, we could answer the question "What did God promise Abraham?" by giving a brief response: God promised Abraham

- a land (Gen. 12:1);

- a nation (Gen. 22:17-18); and

- a blessing to the world (Gen. 17:6).

The answer would be correct but incomplete. Indeed, the tripartite answer is technically true but contextually deficient.

The aim of this article is not only to answer the question in its most reduced format, but to do so within the larger biblical context. That context of God's plan of salvation enriches and strengthens the answer to the question, "What did God promise Abraham?"

We will answer the question by examining the framework for the Abrahamic Covenant (and all the covenants in the Bible) in the Word of God.

\section{A Framework for the Abrahamic Covenant}

The answer to the question must begin with the larger worldview that is at work throughout the entire Bible. That worldview, or paradigm of faith, is grounded in pre-Creation covenant between the Triune God, proclaimed at Creation, promised at the Fall, and, consequently, worked out in space and time from the Fall to the coming of Jesus Christ, and, from His life lived for us and his death for our sins, to the Second Coming, the Final Judgement, and a New Heaven and New Earth. The terms of the Covenant are, thus, extended to all who will call on the name of the Lord.

This cosmic paradigm of God's promises - His covenant to restore Eden by His own righteousness and His own sacrifice - is the scarlet thread of Scripture.

\section{The Scarlet Thread of Scripture}

The Holy Bible is one sweeping epic that extends from eternity past to eternity future. That the single story of Creation, Fall, Redemption, and Consummation is communicated by men called by God and filled with the Holy Spirit, in 66 books, with near forty authors, and thousands of years, is a phenomenal testimony to Scripture's self-evidence of its inerrancy and infallibility. The celebrated English Puritan poet and public intellectual, John Milton (1608-1674), divided the entire plan of salvation revealed in Scripture into two titles: "Paradise Lost (1667)," and "Paradise Regained (1671)." One could hardly imagine any greater and more brilliant observation of the entire story of Scripture. However, the division of the plan of God by those two titles (and Milton's remarkable theological treatise in free verse) is only surpassed by the eponymous 
division the Church has assigned the Old Covenant and the New Covenant, i.e., the Old Testament and the New Testament.

Since the title of this article is, "What did God Promise Abraham?" one may be justified in asking, "Pray tell me, what does your introductory statement on the larger message of Scripture have to do with the more single-minded story of God's promises to Abraham? I quite understand your possible frustration. However, I would respond that my introduction about the unity of the entire Bible with its notable division-whether John Milton's epic titles or the Churches familiar designations - has everything to do with the title of this piece. For every leaf in the book of life is sewn together by a single scarlet thread: the covenant promises of God. That promise of God in Genesis 3:15 is the divinely revealed anchor agreement, or "covenant," from which all the other covenants find their meaning, including the Abrahamic Covenant.

After the act of disobedience by Adam and Eve, the One God in Three Persons announces both a curse and a promise of redemption in what has been called "the first evangel."

\section{The First Gospel}

"And I will put enmity between you and the woman, and between your seed and her Seed; He shall bruise your head, and you shall bruise His heel" (Genesis 3:15).

There is much to say about this one passage:

God's message is directed to Satan who instigated the Fall; and to woman, who first ate of the forbidden fruit, and a reference to the "seed of the woman" - an enigmatic phrase at its biological essence - combined with the promise of a Redeemer, born of woman without reference to the male, who crushes the head of Satan.

This Redeemer's mission of salvation - of humanity and all Creation - is realized at the deadly price of a viperous wound. Yet, we must leave this passage as it is, except to say that this is, indeed, the fountainhead from which we will discover the unconstrained response to the question, "What did God promise Abraham?"

\section{The Covenant of Works and the Covenant of Grace}

Mankind was created and placed into a conditional relationship with God that is rightly called, "The Covenant of Works." In this holy arrangement, Almighty God requires perfect obedience and undivided loyalty. He is God, after all. In return, the Lord offers life and life eternal. The penalty for breaking God's law - a veritable cosmic rebellion - is death. Mercifully, death is not (necessarily) immediate, but is, by this stage, a "monster inside me," to borrow the title of a popular real-life show about larva, snails, and man-eating crustaceans lodged in parts of the human body. Its not a very pleasant mental image, I admit. Neither is death from the inside out. Nevertheless, our loving heavenly Father proclaims another way: what theologians call "The Covenant of Grace." By the way, these covenant phrases are not theological archetypes forced upon the Scriptures, but, are, rather, clear concepts derived directly from the Holy Text. In this God* Initiated arrangement, born out of Adam and Eve's disobedience, and the Lord's plan to enjoy fellowship with His Creation, God promises to do for them (us) what they (we) could not do for themselves (ourselves). God will keep the law perfectly. He will take the punishment for sin. Like our first parents, we are each born into a covenant of works. Yet, none of us can maintain complete obedience to God. Those who believe they can work their way to God are foolishly wagering that their own supposed holiness can provide a perfection of life that the Lord requires. The assume the punishment for our sins. The tragic end of such delusional spiritual bravado will be death and hell. God provides what we are incapable of doing (and being): we are invited to come to the Lord and to plead for his forgiveness and to receive the gift of his grace.

So, this is the framework through which we access the truth of the Abrahamic Covenant and, in doing so, answer the question, "What did God promise Abraham?" 


\section{The Abrahamic Covenant}

Firstly, the Abrahamic covenant is but one of several covenants in the Bible. These promises-flowing from that one great Promise in Genesis 3:15 - are progressive revelations of God's intent. The single. most important book on the centrality of covenants in Scripture, divine promises, if you prefer, is the, now, classic work of Dr. O. Palmer Robertson: Christ of the Covenants (1980).

"The primary covenants in Scripture are those made with Noah, Abraham, Moses, David, and the new covenant [The Lord Jesus at Communion]. In addition, strong evidence favors viewing the original creation relationship between God and man, as well as the first bond established by God with man after the fall, as covenantal." (Robertson, 1980)

Secondly, whilst the Abrahamic Covenant is but one of (at least) seven divine promises from God to Mankind, the Abrahamic covenant is remarkable. It is remarkable in its disclosure of how God will move from an otherwise insignificant band of Semitic peoples, to a land in turmoil, to a nation, to a spiritual realization of the covenant that will bring forth the Messiah, and descendants of Abraham that include the entire world. It is remarkable in that the covenant begins with a grand vision, is, first, realized in a small nation, small piece of land, and a loss of that land because of sin. Thus, some have conceived of the Abrahamic Covenant's as an hourglass. It goes from the large vision to a tiny dot on the earth and, through Jesus, to the ends of the earth. The covenant was never to be limited to merely a piece of ground, or to one nation. How did Isaiah put it? "He says: 'It is too light a thing that you should be my servant to raise up the tribes of Jacob and to bring back the preserved of Israel; I will make you as a light for the nations, that my salvation may reach to the end of the earth.'"

\section{God's Promises to Abraham}

Using an expository statement for each covenantal promise to Abraham, as contributed by Rev. Charles Haynes, Jr., here are the covenantal promises of God to Abram (he was not yet Abraham):

* I will show you where to go.

* I will make you into a great nation.

* I will bless you.

* I will make your name great.

* I will make you a blessing to others.

* I will bless those who bless you.

* I will curse those who curse you.

* I will bless all the people on earth through you.

\section{The New Covenant Interpretation}

The Abrahamic Covenant was about God separating out a man, Abraham, and his wife, Sarah - a new Adam and Eve, with the supernatural manifestation of birth from sterility, as miraculous as creating the world is six days - and bringing them to a land. The covenant was about God's sovereign selection of a man and wife to bring forth a line that would bring forth a Messiah who would bless the world.

Indeed, except for a small dot of light in Israel, and not all of Israel believing, God brought forth the promise to Abraham (and to the other Covenants): our Lord and Savior Jesus Christ. Those who believed did so against the backdrop of Roman occupation, religious corruption, and the constant threat of persecution. Surely many wondered whether the sared covenant to Abraham would be ever be realized. Yet, the faithful ones, like Simeon, like Anna, clung to the promise of God: 
"Behold, the days are coming, declares the Lord, when I will make a new covenant with the house of Israel and the house of Judah, not like the covenant that I made with their fathers on the day when I took them by the hand to bring them out of the land of Egypt, my covenant that they broke,... For this is the covenant that I will make with the house of Israel after those days, declares the Lord: I will put my law within them, and I will write it on their hearts. And I will be their God, and they shall be my people. And no longer shall each one teach his neighbor and each his brother, saying, 'Know the Lord,' for they shall all know me, from the least of them to the greatest, declares the Lord. For I will forgive their iniquity, and I will remember their sin no more" (Jeremiah 31:31-34 ESV).

Jesus proclaimed that covenant fulfillment when he became the life-giving signs of salvation at the Last Supper:

"And he took bread, and when he had given thanks, he broke it and gave it to them, saying,

"This is my body, which is given for you. Do this in remembrance of me." And likewise, the cup after they had eaten, saying, "This cup that is poured out for you is the new covenant in my blood" (Luke 22:19-20).

\section{Who are Abraham's Children?}

The Apostle Paul, who would always pray for the ethnic children on Abraham, declared:

"Know then that it is those of faith who are the sons of Abraham. 8 And the Scripture, foreseeing that God would justify the Gentiles by faith, preached the gospel beforehand to Abraham, saying, "In you shall all the nations be blessed." 9 So then, those who are of faith are blessed along with Abraham, the man of faith" (Galatians 3:7-9); "If you are Christ's, then you are Abraham's offspring, heirs according to promise" (Galatians 3:29).

When God made His covenant with Abraham, He inaugurated a physical line through Isaac, the son of Sarah and Abraham. This was done so that the origin was spiritual, miraculous, and incapable of being traced to anything of merely Man. The Abraham Covenant, which at first seemed global, and eternal, seemed to become quite narrow (remember the hourglass illustration), until the birth of our Lord Jesus Christ. Through His life, death, resurrection, and ascension, and present rule from heaven, the hourglass widened. By our Savior's ascension, the Gospel began to spread. By the time of the death of the last Apostle to die, John in Ephesus, the Gospel of Jesus Christ had gone from Europe to India, from Africa to Asia. The Gospel is a centrifugal force. The family of God is growing as billions of human beings have become the children of Abraham. They are from every tribe, tongue, and nation. The Old Covenant is fulfilled in Jesus. The New Covenant is underway.

What did God promise Abraham? If you will trust in Jesus Christ, the greater Son of Abraham, who became the living Mediator of the Covenant of Grace - He lived the life you could not; and He died the death that should have been yours - you will become the living answer to the promise. For you will be not just a child of Abraham. You will be a child of God.

\section{Bibliography}

Clarence L. Haynes, Jr. 2021. "5 Things to Know about God's Promise to Abraham." Crosswalk.Com. April 9, 2021. https://www.crosswalk.com/faith/bible-study/things-to-know-about-gods-promise-toabraham.html.

Milton, John. 2012. Paradise Regained, Samson Agonistes, and the Complete Shorter Poems. Modern Library.

Milton, John, and Judith Boss. 1997. Paradise Lost (1667). RS Bear. 
Robertson, O. Palmer. 1980. The Christ of the Covenants. Baker Book House.

"Westminster Confession of Faith: The 1647 Edition." 2013. July 13, 2013. http://www . covenantofgrace. com/westminster_confession.htm.

\section{References}

Christ of the Covenants. (1980). Baker. 